\title{
Åsa Wedin
}

Högskolan Dalarna

Jenny Rosén

Stockholms universitet

DOI: http://doi.org/10.5617/adno.8361

\section{Språkliga normer i förskollärarutbildning: Ett kritiskt perspektiv}

\begin{abstract}
Sammanfattning
Syftet med denna studie är att utifrån ett kritiskt perspektiv bidra med kunskap om språkideologier inom lärarutbildningen i Sverige. För att möjliggöra en likvärdig skola menar vi att det är centralt att förskollärare och lärare utvecklar arbetssätt för att ge alla barn och elever oavsett språkliga erfarenheter möjlighet att utvecklas. Fokus riktas här mot språkideologier i svensk lärarutbildning genom att undersöka hur ideologiska rum och rum för implementering av språklig mångfald konstrueras och förhandlas inom förskollärarprogrammet. Det empiriska materialet har skapats under fyra år genom observationer, individuella intervjuer och fokusgruppsamtal med lärarutbildare och studenter när vi följde en grupp studenter som på grund av sin migrationsbakgrund valts ut och getts stöd för att delta i förskollärarprogrammet. Analysen visar på en rådande enspråkig norm för standardiserad svenska såväl i förskollärarutbildningen som för studenternas framtida arbete som förskollärare, och att en förutsättning för att bli en erkänd medlem i denna grupp var att följa denna norm. Ideologiska utrymmen för flerspråkighet skapades under utbildningen men möjligheter att implementera dessa var få. En spänning fanns mellan å ena sidan pluralism och mångfald och å andra sidan ett starkt krav på anpassning av språkanvändning för minoritetsstudenter till en enspråkig standardiserad norm. Som lärarutbildare inser vi värdet och kanske nödvändigheten av en gemensam språklig norm, och även att denna i hög grad behöver gälla skriven text. Samtidigt argumenterar vi för att öppna lärarutbildningen för en flerspråkig pedagogik som inkluderar och stärker både studenternas språkliga repertoarer och ger dem möjlighet att utveckla förhållningssätt och arbetssätt för att arbeta i verksamheter präglade av språklig mångfald.
\end{abstract}

Nyckelord: flerspråkighet, språkliga normer, förskollärarutbildning, ideologiskt utrymme

\section{Linguistic norms in preschool education: A critical perspective}

\begin{abstract}
The aim of this article is to generate knowledge about language ideologies in teacher education in Sweden from a critical perspective. In order to achieve an equal education, we argue that it is important that teachers are able to develop an approach and pedagogy that can support all pupils despite their linguistic background to achieve the goals in school. The focus of this article is on language ideologies in teacher education for
\end{abstract}


preschool teachers and how ideological and implementational spaces for language diversity is constructed and negotiated in the education. The empirical material was produced during four years through observations, individual interviews and focus group interviews with educators in the teacher education and a group of ten students in the preschool teacher program, who were admitted to the program based on their migration background. The analysis shows that there is a monolingual standardized norm for Swedish both prevailing in the teacher education and pointing towards their future jobs as preschool teachers. In order to become legitimate members in the group of preschool teacher students and a future community of practice of preschool teachers, the students adjusted to this norm. We identified ideological spaces for multilingualism in the education but the possibilities to implement them were few. Thus, there was a tension between pluralism and diversity on the one side and a strong demand for adjustment to a monolingual standardized language norm for minority students on the other side. As teacher educators we realize the value and necessity of a common language norm, and we are as scholars reproducing such norms of academic language through the writing of this article. At the same time, we argue that it is important to include a multilingual pedagogy in the teacher education that can i) include and support the linguistic repertoires of students in the program and ii) prepare students for their future work in language heterogenous preschools and schools.

Keywords: multilingualism, linguistic norms, preschool teacher education, ideological space

\section{Introduktion}

De senaste årtiondena har karakteriserats av konstant, snabb och oförutsägbar mobilitet vad gäller människor, varor och texter (Blommaert, 2010; Holm \& Pitkänen-Hutha, 2012). Denna mobilitet har innefattat såväl migration och ökat resande där människor förflyttar sig fysiskt över gränser, som en digital mobilitet där människor kan kommunicera och konsumera över en stor del av världen. Detta innebär att mänsklig interaktion kan karaktäriseras med begreppet superdiversitet (super-diversity) (Vertovec, 2007, 2019). Dessa förändringar på samhällsnivå aktualiserar frågor om språk och utbildning och i denna artikel vänder vi vårt intresse mot lärarutbildningen. Samtliga lärosäten i Sverige har ett uppdrag att arbeta med breddad rekrytering, sedan detta skrivits in i högskolelagen 2001. I artikeln riktas fokus mot språkideologier inom svensk förskollärarutbildning genom att undersöka vad som uppfattas vara önskvärt skrivande bland lärarstudenter i relation till ökad språklig mångfald i samhället generellt och i förskolan specifikt. Formell utbildning, inklusive lärarutbildning, kan förstås som en centrala arenor för tolkning av, förhandling med och utmaning av språknormer och språkideologier (Hornberger \& Johnson, 2007)

Enligt den svenska språklagen är svenska huvudspråk i Sverige och "var och en som är bosatt i Sverige ska ges möjlighet att lära sig, utveckla och använda svenska." (SFS, 2009:600, §14). Syftet med språklagen är "att ange svenskans och andra språks ställning och användning i det svenska samhället. Lagen syftar 
också till att värna svenskan och den språkliga mångfalden i Sverige samt den enskildes tillgång till språk.” (SFS, 2009:600, §2). Språklig mångfald har ökat i det svenska samhället, i synnerhet som en följd av migration, och $28 \%$ av alla elever i grundskolan är berättigade till modersmålsundervisning, vilket innebär att de använder minst ett annat språk än svenska i hemmet (Skolverket, 2019). Ökningen vad gäller antalet invånare med migrationsbakgrund i Sverige har dessutom resulterat i en ökning av antalet barn och elever med svenska som sitt andraspråk, som växer upp i hem där andra språk än svenska dominerar, samtidigt som ett ökande antal elever födda i Sverige växer upp i miljöer där andra språk än svenska används frekvent. Emellertid indikerar studier att den språkliga mångfalden i samhället inte återspeglas i innehållet i svensk lärarutbildning (Zilliacus, Paulsrud \& Holm, 2017; Paulsrud \& Zilliacus 2018) och att framtida lärare därmed inte förbereds för att möta en språkligt heterogen elevgrupp. Zilliacus et al. (2017) visar dessutom att existerande mångfald i svenska skolor inte är tydligt synlig i nationella läroplaner och att synen på kultur i läroplanen är statisk trots en diskurs av "en skola för alla”.. Detta kan resultera i bristande likvärdighet i utbildningssystemet eftersom lärare kanske inte beaktar individuella elevbehov eller de mångfaldiga och multipla identiteter som kan hittas i ett klassrum. Samtidigt visar statistik att andelen elever, som vid utgången av årskurs 9 var behöriga till gymnasieskolan, endast var 32\% för elever som invandrat till Sverige i årskurs 6-9 (eller med okänd bakgrund) och 68\% för elever som invandrat i årskurs 1-5 jämfört med 91\% för elever med svensk bakgrund (Skolverket, 2020).

För att möjliggöra en likvärdig skola menar vi att det är centralt att förskollärare och lärare utvecklar förhållningssätt till och arbetssätt för att ge alla barn och elever oavsett språkliga erfarenheter möjlighet att utvecklas. Det fåtal studier som existerar om flerspråkighet inom lärarutbildning pekar mot en ambivalens där flerspråkighet å ena sidan ses som ett mål för alla elever i skolan genom studier i engelska och moderna språk, medan å andra sidan den språkliga heterogenitet som finns i många klassrum betraktas som ett problem. I denna studie riktas dock fokus mot förskollärarutbildningen. I examensmålen för förskollärarutbildning (Högskoleförordningen 1993:100, bilaga 2) uttrycks att studenten ska "visa förmåga att ta till vara barns kunskaper och erfarenheter för att stimulera varje barns lärande och utveckling" samt "visa förmåga att observera, dokumentera och analysera barns allsidiga lärande och utveckling i förhållande till verksamhetens mål och informera och samarbeta med vårdnadshavare”. I ett samhälle som präglas av språklig mångfald är det relevant att synliggöra hur förskollärare ges möjlighet att utveckla kunskap om hur de möter barn och vårdnadshavare med olika bakgrund. Samtidigt innebär målet om breddad rekrytering inom högre utbildning att språkfrågor aktualiseras även genom studenternas skilda bakgrunder. Genom att fokusera språkideologier inom förskollärarutbildning vill vi här skapa förståelse för hur rum för flerspråkiga praktiker kan skapas (Hornberger \& Johnson, 2007). På så sätt riktas fokus mot 
praktiker som stödjer social jämlikhet och främjar mångfald inom högre utbildning. Hornberger och Johnson argumenterar för vikten av ökad kunskap om hur rum för flerspråkighet skapas inom utbildning, såväl ideologiska rum som rum för implementering (ideological and implementational spaces), och hur dessa öppnas och stängs.

Syftet med denna studie är att utforska språkideologier i svensk lärarutbildning genom att undersöka hur ideologiska rum och rum för implementering av språklig mångfald konstruerades inom förskollärarprogrammet vid ett svenskt lärosäte med en grupp fokusstudenter som antogs till programmet på grund av sin migrationsbakgrund. Följande forskningsfrågor ligger till grund för studien:

1. Vilka språkliga praktiker framstår som önskvärda inom förskollärarprogrammet?

2. Vilka språkliga ideologier framträder inom ramen för förskollärarprogrammet?

3. Hur skapas, upprätthålls, förhandlas eller utmanas dessa språkliga ideologier?

4. Hur positioneras eller positionerar sig fokusstudenterna i relation till dessa språkliga ideologier?

Genom att använda ett kritiskt språkvetenskapligt ramverk riktas fokus mot förhandling av språknormer som uttryck för språkideologier. I studiet av hur lärare och studenter implementerar, tolkar och eventuellt motsätter sig normer vill vi skapa kunskap om hur språklig mångfald behandlas inom förskollärarprogrammet. Med utgångspunkt i ett tidigare forskningsprojekt om studenter med migrationsbakgrund på förskollärarprogrammet (Rosén \& Wedin, 2018, 2019) analyseras hur språkideologier konstrueras i det rum som förskollärarprogrammet utgör. Slutligen diskuterar vi studiens resultat i relation till frågan om breddad rekrytering inom högre utbildning och i relation till förskollärares uppdrag.

\section{Teoretisering av språklig mångfald i högre utbildning}

Det teoretiska ramverket utgörs av ett kritiskt perspektiv som betonar relationer mellan språk och makt, där språkliga ideologier utgör en central del. Språkideologi beskrivs av McGroarty (2010, s. 3):

Whether explicit or implicit, language ideologies inevitably incorporate, often unconsciously, speakers' sometimes-idealized evaluations and judgments of appropriate language forms and functions along with opinions about individuals and groups that follow or flout conventional expectations. 
Utifrån detta perspektiv synliggörs hur en ökad språklig mångfald som ett resultat av en global mobilitet också inbegriper frågor om social ojämlikhet (se bl.a. Blommaert, 2010; Kell, 2017). Inom ramen för vad som har kallats the multilingual turn (May, 2014; Conteh \& Meier, 2014) har mobilitet, förändring och komplexitet ersatt tidigare förståelser av språk som stabila (Blackledge \& Creese, 2010; Blommaert \& Rampton, 2012; Canagarajah, 2018). I motsats till tidigare uppfattningar om språklig homogenitet som eftersträvansvärd, argumenterar forskare som Gal (2006), Makoni \& Pennycook (2007) och May (2014) att även begreppet språk i sig utgår från europeiska begrepp som nationalism och kolonialism. I linje med dessa argument utgörs grunden för denna artikel av ett kritiskt perspektiv på flerspråkighet i relation till utbildning, och genom att bygga vidare på exempelvis Canagarajah (2018) förstås språk som situerat och inbäddat i materiellt liv, och språkliga normer och ideologier som inbäddade i och samtidigt konstruerade av maktrelationer.

Frågor om språk och ideologi har länge intresserat sociolingvistiska forskare, inte minst i relation till utbildning. Forskare som Fishman (1974) och Haugen (1972) lade grunden för forskning om språkplanering, särskilt på nationell nivå. Ruiz (1984) formulering av orienteringar inom språkpolicy för utbildning genom språk som problem, rättighet eller resurs har utvecklats till vad Ricento och Hornberger (1996) kallar neoklassiska eller kritiska inriktningar för språkpolicyforskning. I denna kritiska inriktning betonas samtida språkideologiers relation till den koloniala historien och nationalstatsprojektet som legitimerande av en europeisk institutionell epistemologisk auktoritet (se exempelvis Makoni \& Pennycook (2007) och Rosa \& Flores (2017)). Rosa och Flores (2017) hävdar att ett visst språkbruk och dess användare marginaliserats och rasifierats ${ }^{1}$ genom dessa processer.

Genom kritiskt inriktade studier kan de dominerande paradigm och ideologier som medför att vissa språk favoriseras på minoritetsspråkens bekostnad synliggöras. Ramanathan (2005) och Skilton-Sylvester (2002) har visat hur lärare kan utforma undervisning så att elevernas tidigare språk används som resurser i klassrum trots officiella enspråkiga ideologier. På så sätt skapas ideologiska rum för studenters flerspråkighet. Hornberger och Johnson (2007) visar genom longitudinella etnografiska studier hur ideologiska rum och rum för implementering av flerspråkig utbildningspolicy och -praktik öppnas och stängs. Hornberger (2005) hävdar att även om top-down policies kan stänga ideologiska rum kan rum för implementering av flerspråkighet konstrueras genom bottom-upprocesser som skapar lokala ideologiska rum. Ricento och Hornberger (1996) betonar att lärare kan utöva makt över språkpolicy genom att i sina didaktiska beslut välja att inkludera minoritetsspråk och på så sätt skapa rum där

\footnotetext{
${ }^{1}$ Begreppet rasifiering används i denna studie med grund i Molina (2005) för att synliggöra hur föreställningar om ras har påverkan på människors liv både i form av privilegier, marginalisering och diskriminering. Enligt Molina "står begreppet rasifiering för kategoriseringar, tankemodeller och associationer som gör rangordningen mellan människor till ett naturligt inslag i såväl sociala relationer som maktstrukturer” (2005, s. 95).
} 
flerspråkighet används som resurs, alternativt välja att inte inkludera minoritetsspråk och på så sätt stänga potentiella rum. (För exempel se SkiltonSylvester (2002) och Hornberger \& Johnson (2007).)

Under begreppet raciolinguistics fokuserar Flores and Rosa (2015) vad de kallar "the white listening subject" (det vita lyssnarsubjektet) som en del i upprätthållandet av enspråkiga ideologier. Utifrån en enspråkig ideologi används begrepp som standardsspråk som neutrala beskrivningar trots att de kanske inte är empiriskt representerade. Att använda kategorier som andraspråkstalare och icke infödd talare reproducerar ett bristperspektiv, där språkbruket också rasifieras. Därmed positioneras den rasifierade talaren som underlägsen det vita lyssnande subjektet och som språkligt underlägsen oavsett språkanvändning (Flores \& Rosa, 2015). Pedagogiska förhållningssätt som bygger på språklig lämplighet utmanas av en växande litteratur om heteroglossiska språkpraktiker (García, 2009) och kritisk språklig medvetenhet (Alim, 2016 Flores \& Rosa, 2015). Detta kan, enligt Flores och Rosa, synliggöra den rasism som de uppfattar som inbyggd i dominerande undervisningspraktiker, praktiker som kan upprätthållas genom att marginalisering utifrån vad som anses vara standardnormer framställs som objektiva. I en svensk kontext blir detta relevant när frågan om studenters bristande språkförmåga framställs som ett problem och hot mot kvaliteten i utbildningen. Utifrån Flores och Rosas (2015) utgångspunkt kan fokus flyttas från de marginaliserades föreställda brister till majoritetens oförmåga och/eller ovilja att lyssna och förstå minoriteter.

\section{Tidigare forskning om språklig mångfald i lärarutbildning}

I relation till högre utbildning i Sverige har tidigare studier identifierat en enspråkig norm (Lennartsson-Hokkanen, 2016, Bayati, 2014; Bigestans, 2015). Bigestans studie visade att lärare med invandrarbakgrund kände att i synnerhet deras uttal betraktades som undermåligt, och att deras auktoritet ifrågasattes. Bigestans hänvisade till lingvisism (se Phillipson \& Skutnabb-Kangas, 1986; Phillipson, 1992, för begreppet) i form av omotiverad uppmärksamhet på lärarnas status som andraspråksanvändare av svenska. Hon argumenterar att det inte finns tillräckliga och tydliga mål vad gäller mångfald och att det finns behov av kritisk analys av rådande normer bland skolpersonalen. Vidare visade Bayati (2014) i en studie att lärarstudenter med invandrarbakgrund upplevde diskriminering och rasism och framställdes som den Andre under sin utbildning. I en studie av språkstöd för andraspråksstudenter fann Lennartsson-Hokkanen (2016) att språkstödet synliggjorde en enspråkig norm, vilket resulterade i att avvikelser och variationer i andraspråkselevernas texter som återspeglade deras språkutveckling uppfattades som brister.

I en studie om flerspråkighet och interkulturalitet i lärarutbildning i Finland och Sverige fann Paulsrud och Zilliacus (2018; Hummelstedt-Djedou et al., 2018) 
att lärarutbildarna och lärarstudenterna var positiva till mångfald och att ideologiska rum, men inte rum för implementering, konstrueras i lärarutbildningen i båda länderna. Både lärare och studenter uttryckte positiva attityder gentemot flerspråkighet och interkulturalitet. Trots det fanns det inget utrymme för implementering. Paulsrud och Zilliacus argumenterar att officiella diskurser kan öppna eller stänga rum genom att skapa sådana utrymmen och att utvecklingen av kritisk, flerspråkig medvetenhet bland lärare är kopplad till frågor om social rättvisa och inkludering.

Även Paulsrud och Lundberg (2021) uppmärksammar genom en studie av kursplaner inom lärarutbildningar vid två lärosäten att kunskap om språklig och kulturell mångfald främst behandlas inom kurser i språk (engelska och svenska) men också i viss omfattning inom kurser i den utbildningsvetenskapliga kärnan. Trots förekomsten av lärandemål och innehåll som belyser språklig och kulturell mångfald i kursplanerna ifrågasätter författarna om lärarstudenter förbereds för arbetet i dagens skola och förskola.

I vår studie av studenter på förskollärarprogrammet för vilka svenska var ett andraspråk (Rosén \& Wedin, 2018, 2019) fann vi en ambivalens i relation till mångfald. I studien framstod de språkliga normerna inom programmet som begränsande för studenters möjligheter till framgång, något som blev uppenbart när det gällde krav på skriftlig språkfärdighet.

\section{Material}

Materialet för denna artikel skapades genom ett fyraårigt projekt, På tröskeln till förskolan: Förskollärares utbildning i en flerspråkig, mångfaldskontext. Projektet hade etnografisk utgångspunkt och syftet var att belysa och problematisera frågor om språklig mångfald i förskollärarutbildningen genom att följa tio studenters vägar genom utbildningen. Denna grupp studenter hade valts ut av kommunen på grund av sin migrationsbakgrund för att ges stöd att delta i förskollärarprogrammet. Syftet med insatsen från kommunen var dels att stödja individernas etablering på arbetsmarknaden, dels att långsiktigt kunna anställa dem som färdiga förskollärare med flerspråkig och interkulturell kompetens. De som genomförde urvalet betonade värdet av studenternas varierade språkliga och kulturella bakgrund för deras framtida roll som förskollärare. Inte alla utvalda uppfyllde behörighetskraven för antagning till programmet och därför erbjöds stöd för dem som behövde det för att fullfölja de sista kurserna i svenska som andraspråk.

Data samlades in under närmare fyra år, främst genom intervjuer, observationer och dokument såsom kursplaner. Intervjuer med studenterna genomfördes under olika skeden av utbildningen, såväl individuellt som i grupp. Av olika skäl var det bara fyra av de utvalda studenterna som fullföljde studierna inom de normala 3ํㅡㄹ åren, och ingen fick sin lärarexamen inom utsatt tid. Några 
lämnade programmet eller genomförde det inte inom den stipulerade tiden av hälsoskäl eller icke godkända resultat. Totalt genomfördes 20 individuella intervjuer och två fokusgruppsintervjuer. Lärare på förskollärarprogrammet och lärare som erbjöd språkstöd intervjuades också, totalt 12 lärarintervjuer. Samtliga intervjuer audioinspelades och transkriberades. Ungefär 40 timmar av observation genomfördes, dokumenterade genom fältanteckningar, och dessa observationer inkluderade seminarier, verksamhetsförlagd utbildning och möten i den initiala planerings- och rekryteringsprocessen.

Materialet skapades således under de 31즐 år som var den stipulerade tiden för programmet. Ett antal etiska överväganden aktualiserades i studiens olika skeden. Fokusstudenterna studerade tillsammans med studenter som antagits enligt gängse antagningsprocedur, vilket hos vissa skapade misstro gentemot den grupp studenter som antagits genom stöd från den aktuella kommunen. Detta resulterade i vissa konflikter under det första året, och på grund av detta avstod vi från att genomföra observationer under de två första terminerna. Observationer i lärarutbildning under seminarier och studentpresentationer inkluderade även observation av personer som var kända för oss genom lärarutbildning och forskning, något som krävde eftertanke. Vid intervjuerna med lärarutbildarna förhöll dessa sig i vissa fall till oss som "en av dem” samtidigt som vi också positionerades som forskare med intresse för flerspråkighet och andraspråk snarare än med fokus på förskolan. Alla studenter och lärare som observerades informerades om studien och gav skriftligt och muntligt samtycke för sin medverkan. Vid tiden för studiens genomförande rådfrågades även den lokala forskningsetiska nämnden vid lärosätet. I presentationen av materialet har vi strävat efter att anonymisera lärarutbildare och studenter och vi har därför valt att inte referera till lokala styrdokument på lärosätet eller ange mer information om informanterna än vad som varit relevant för artikelns fokus.

För denna artikel har material från observationer och intervjuer med studenter och lärarutbildare analyserats. I ett första steg har ramarna för det ideologiska rum som förskollärarprogrammet utgör analyserats genom en innehållsanalys av nationella och lokala styrdokument för högre utbildning och förskollärarutbildning specifikt (högskolelagen, högskoleförordning, språklagen SFS 2009:600, lärosätets lokala språkpolicy vid tidpunkten för studien och utbildningsplan för förskollärarutbildningen). I ett andra steg har material från observationer och intervjuer analyserats med fokus på i) hur språkliga normer uttrycks av lärarutbildare och studenter under observationer vid seminarier, ii) när och hur lärarutbildarna talar om studenternas språkanvändning och kompetens, och iii) hur fokusstudenterna talar om språkanvändning i utbildningen samt hur de positionerar sig i relation till språkliga krav och förväntningar. I analysen har materialet analyserats för att identifiera kritiska händelser där frågor om språk och språklig kompetens uppmärksammats. Eftersom vi båda har lång erfarenhet av att undervisa inom lärarutbildning har en strävan i analysprocessen varit att synliggöra och ifrågasätta praktiker som varit förgivettagna. 


\section{Resultat}

Inledningsvis kommer ramarna för det ideologiska rum som förskollärarprogrammet utgör att behandlas med utgångspunkt i styrdokument på nationell och lokal nivå. Därefter används observationer och intervjuer för att besvara forskningsfrågorna. Först analyseras önskvärda språkliga praktiker och framträdande språkliga ideologier, följt av analys av hur dessa språkliga ideologier skapas, upprätthålls, förhandlas eller utmanas. Detta följs av analys av hur studenterna positioneras och positionerar sig i relation till dessa ideologier.

\subsection{Förskollärarprogrammets ideologiska ramar}

I denna del riktar vi fokus mot den uttalade språkpolicyn på nationell och lokal nivå. Med stöd i språklagen (SFS, 2009:600) är svenska huvudspråket i Sverige och den offentliga sektorn har särskilt ansvar för att använda och utveckla svenska. Högre utbildning har en viktig roll vad gäller det svenska språket. På lokalnivå har även flera lärosäten utformat policydokument för språkanvändning inom verksamheten (Hult \& Källkvist, 2016a, 2016b). I den debatt som föregick språklagen positionerades högre utbildning och forskning som domäner där engelska dominerar på svenskans bekostnad (Boyd \& Huss, 2001; Melander, 2007; Salö, 2010). Sålunda har frågan om engelska i högre utbildning beskrivits som en spänning mellan å ena sidan nationella mål för bevarande av svenska som huvudspråk och å andra sidan internationaliseringsrelaterade mål och målet att vara en del av en internationell forskningsgemenskap (Gunnarsson, 2004; Hult \& Källkvist, 2016a). Förutom frågan om engelska visavi svenska har andra språks status i högre utbildning sällan aktualiserats. Inom barn- och ungdomsskolan har betydelsen av ett flerspråkigt förhållningssätt där elevernas språkliga repertoarer erkänns och används som resurser alltmer kommit att betonas både i forskning och policydokument. Någon motsvarande förändring inom högre utbildning framträder dock inte i vår analys.

Lärosätet där denna studie genomfördes hade vid tiden för studien en lokal språkpolicy $^{2}$ som tog sin utgångspunkt i språklagen (SFS 2006:900). Denna policy stipulerade att alla lärare och övrig personal ska behärska både svenska och engelska på lämplig nivå. Vidare arbetade man vid lärosätet med att försäkra sig om att det finns en klar och systematisk progression i språkanvändning vid dess utbildningsprogram och att studenter har tillfälle att utveckla klara och lämpliga språkfärdigheter såväl i svenska som engelska. Policyn nämner specifikt studenter vilkas modersmål inte är svenska eller vilkas svenskfärdigheter eller erfarenheter av akademisk litteracitet är begränsade. Den fastslår även att det är lärarnas ansvar att identifiera sina studenters språkproblem och att hitta sätt för dem att utveckla sina (svensk- och engelsk-) språkliga färdigheter i enhetlighet med akademiska normer.

\footnotetext{
${ }^{2}$ Av anonymitetsskäl kommer fullständiga referenser till det aktuella dokumentet inte att ges. Språkpolicyn är inte heller längre i bruk vid det aktuella lärosätet.
} 


\section{2 Önskvärda praktiker och framträdande språkliga ideologier}

Vi börjar med att identifiera språkliga praktiker som framstår som önskvärda och språkliga ideologier som framträder. Svenska var det språk som vanligen observerades i seminarierna genom programmet, och studenterna behövde använda svenska i olika former av muntlig interaktion, såsom vid gruppdiskussioner, muntliga presentationer, diskussioner om frågor eller ämnen kopplade till kurslitteraturen och diskussioner kring skriftliga uppgifter som studenterna lämnade in inför seminarierna. Under föreläsningar gavs studenterna vanligen utrymme att uttrycka sina åsikter, argumentera och ge förslag. Fokusstudenterna observerades ofta vara aktivt deltagande i diskussionerna och väl förberedda inför seminarier. Ett exempel är att de ofta redovisade seminarieuppgifter genom väl genomarbetade Power Pointpresentationer.

Medan fokusstudenterna inte sa mycket om sina språkliga färdigheter under intervjuerna talade lärarna desto mer om studenternas (svaga) språkliga förmåga. I lärarnas tal refererade "språk” alltid till svenska, och i synnerhet till akademiska normer för skriven svenska. Lärarna sade sig värdesätta mångfald bland studenterna högt. De insåg också betydelsen av att ha dessa studenter i programmet eftersom de förde med sig en mångfald som var viktig både för programmet i sig och för de förskolor de senare skulle arbeta inom. Samtidigt upplevde de flesta av dem att vissa av dessa studenter hade "kommit för tidigt" med hänsyn till en låg förmåga i svenska. I en intervju under den första terminen fastslog en lärare följande som svar på en fråga om hur den första delkursen förflutit:
Excerpt $1^{3}$.
sen är det en kvinna till som inte klarar ... kursmålen nu i första kursen hon kom för tidigt kan man väl säga på grund av sina hon har inte svenskan tillräckligt hon har inte förstått allt det här med som man ska förstå Q [lärplattform] och inlämningar och hur man skriver och ... så hon har inte förstått ... det verkar som att det är ... språkförståelsen som saknas hon har inte förstått anvisningar och men däremot så har hon ju inte varit rädd för att fråga så utan hon har ju frågat alla som hon har stött på

Talet om att studenterna inte var färdiga och inte hade "tillräckligt god" svenska visar på uppfattningen att vissa färdigheter i svenska ansågs nödvändiga för att kunna tillgodogöra sig utbildningen. Det faktum att denna student inte passade in i den förväntade normen blir tydligare under en intervju med en lärare, som vid ett flertal tillfällen talade om studentens bristande förståelse och hur denna "inte förstått vad man ska förstå”. Lärarna hävdar sålunda att de värdesätter studenternas mångfald, men när det kommer till språkfärdigheter är de endast svenska som synliggörs, och skriven, akademisk svenska det som bedömning av

\footnotetext{
${ }^{3}$ Transkriptionerna är gjorda så att de följer nära det sagda. Därför har sällan stor bokstav och punkt använts för att markera mening. Tecknet ... markerar en längre paus eller uppehåll i taltur. Småord som ”mm” och ”ja” i annans taltur är inte utsatta. Ord inom parentes, (berättar), står för uttryck där det är svårt att avgöra vad som egentligen sägs. Fet stil används för att markera författarnas betoning.
} 
färdigheter ofta baserades på. Som citatet visar förklarade läraren också studentens bristande förståelse vad gäller digitala plattformar, instruktioner och inlämningsuppgifter med studentens låga färdigheter i svenska. Färdigheten i svenska framställdes därmed som centralt för att kunna delta som student i den aktuella praktiken.

Samtidigt blev det tydligt genom intervjuerna att den uppfattade låga språkliga nivån inte enbart var i relation till de studenter som var i fokus i projektet utan snarare i relation till studenter i allmänhet - inklusive förstaspråkstalare av svenska. Många av lärarna konstaterade att studenterna generellt, det vill säga inte bara fokusstudenterna, "skrev för krattigt” och nämnde specifika språkfel, så som sammanblandningen av de svenska pronomina de/dem/dom. De betonade att många studenter, inklusive sådana som kategoriseras som svenska studenter, hade svårigheter med att klara kurserna. Därmed lades stor kraft på att undervisa studenterna i akademiskt skrivande, samtidigt som lärare kom överens om att prioritera innehåll framför språklig korrekthet vid bedömning. När lärarna talade om studenternas språkförmåga var måttstocken svenskans akademiska normer. Inkluderingen av studenter med så kallad svensk bakgrund bland dem som uppfattades som svagpresterande visade emellertid att en uppfattning om en viss nivå vad gäller standardsvenska färdigheter existerade och var betydelsefull vid bedömning av alla studenter.

Bristperspektivet och behovet av att rätta sig efter standardiserad akademisk svenska kunde av enskilda fokusstudenter upplevas som att det begränsade möjligheterna till deltagande. Tre av fokusstudenterna uttryckte att de hade svårighet med att tala inför gruppen. På en direkt fråga om hon har berättat något för de andra eller om hon har framfört sin åsikt säger hon:

\section{Excerpt 2.}

Jag vet inte ibland när det krävs att vi diskuterar jag jag säger min åsikt och säger nånting men jag kan inte säga som dom berättar och ... jag säger bara flera ord två meningar och tyst

Excerpt 2 beskriver studentens upplevelse av att inte kunna använda svenska som övriga studenter "som dom berättar" och därför som förhindrad att uttrycka sig trots vetskapen att kursen kräver aktivt deltagande i seminarier. Studenten beskriver hur hon tystnar under seminarier. En annan student beskriver hur hon fann det svårt att prata med andra studenter under grupparbete för att hon var orolig att hon skulle säga något på fel sätt. På frågan om hon tycker att det blivit bättre under utbildningens gång svarar hon jakande men intervjuaren kommer då tillbaka till om det ändå känns jobbigt.

Excerpt 3.

Intervjuare: men det känns jobbigt fortfarande?

Student: ja det känns jobbigt fortfarande ja men det blir lite bättre och vi har studiegrupp förra gången jag kunde inte prata under studiegruppen eller seminarium men mm ja öh 
ja kanske jag förstår va läraren säger å jag vill uttrycka mina åsikter men ändå jag kan inte jag kanske tänker själv nä kanske dum uttalar fel eller säger fel ord så där

Excerpt 3 visar hur studenten tydligt kopplar sin språkliga performans till rädslan för att uppfattas som ”dum” för att hon uttrycker något på fel sätt. Utdragen visar hur de två studenterna lyfter fram sitt behov av att tala tydlig och korrekt svenska under seminarier och grupparbeten, och hur deras oro över att inte uttrycka sig tillräckligt väl ibland tystade dem. Fokusstudenterna betonade även vikten av en tydligt reglerad talarordning under seminarierna, eftersom de sa att det hjälpte dem att komma till tals även om detta också innebar en ansiktshotande situation. På direkt fråga om vilken ordning hon föredrog svarade en student:

Excerpt 4.

Student: $\quad$ Med N [lärarutbildare] jag pratade inte jag vet inte jag var tyst Intervjuare: $\mathrm{Mm}$ men så är det ju

Student: $\quad$ För att med det som $\mathrm{O}$ [lärarutbildare] pratar en i taget Intervjuare:Att hon ger ordet till en och en är det lättare då är det lättare att hon säger $\mathrm{X}$ [studentens namn] vad säger du? och så blir det tyst och alla väntar på vad du ska säga är det lättare då att prata?

Student: Ibland bättre ibland svårare för att det jag kan inte svara på frågan

Utifrån detta kan förstås att studenterna uttryckte oro över sin oförmåga att delta till fullo i en enspråkigt dominant kontext och att de upplevde att tydlighet vad gäller talarordning underlättade, även om det också riskerade att synliggöra deras osäkerhet. Attityden gentemot andra språk än standardformer av svenska och engelska kan beskrivas i termer av tolerans och acceptans men inte som resurser vare sig i förskollärarutbildningen eller för deras framtida arbete bland barn. Fokusstudenterna rekryterades på grund av sin migrationsbakgrund och flerspråkighet vilken antogs gynna barn som också hade liknande bakgrund. Samtidigt fanns det inget utrymme $i$ undervisningspraktikerna för fokusstudenternas språkliga mångfald, och de uppmuntrades inte heller att använda och utveckla andra språk än svenska när det gällde programinnehåll. Trots att lärarna uttryckte sin uppskattning för mångfald, blev detta enbart synligt i begränsad utsträckning vid seminarier och presentationer men inte i de skriftliga examinationer som fungerade som grindvakter till professionen.

En norm framträder här som är enspråkig och som medför att fokusstudenternas språkliga resurser osynliggörs och inte inkluderas i deras yrkesmässiga utveckling som framtida förskollärare. Detta blev tydligt när fokusstudenterna talade om sin verksamhetsförlagda utbildning under en fokusgruppintervju mot slutet av programmet, där en av studenterna hävdade att hon aldrig skulle använda somaliska, vilket var hennes starkaste språk, till ett barn på förskolan. Excerpt 5 följer på ett samtal mellan studenterna i gruppen om vilka fördelar de ser med att de som blivande förskollärare har en kompetens i flera språk. En av studenterna menar att hennes närvaro på förskolan gör att personalen 
inte behöver ringa in en tolk vid kommunikationen med vårdnadshavare. Studenten i excerpt 5 ger dock i ett fokusgruppsamtal uttryck för en mer restriktiv syn på användning av andra språk än svenska och att detta kan göras "ifall en pedagog frågar mig” i kommunikation med andra vuxna men aldrig med barnen på förskolan:

\section{Excerpt 5.}

Nej alltså hjälper till pedagogerna har ingenting det här med språket och använda med barn som man med såna språk det går inte för mig för jag jag använde mig inte av somaliska när jag pratar med barnen i förskolan men ifall en pedagog frågar mig $X$ [studentens egna namn] kan du förklara det här för att det är så och så eller om det blir missförstånd mellan vuxna men kan jag då tolka, men ett barn nej aldrig.

Den rådande enspråkiga normen inom programmet i relation till förskolans kontext blir tydlig; svenskan är språket, medan andra språkliga resurser osynliggörs eller inte ges utrymme. Genom att tala om "sådana språk” refererar studenten till andra språk än svenska, och det är viktigt att lägga märke till att hon säger att”det går inte för mig” där hon implicit gör detta möjligt för andra. Samtidigt undervisades studenterna explicit om värdet av att uppmuntra och stödja elevernas olika språk i flera kurser. Denna pluralistiska ideologi var emellertid mindre synlig i vad fokusstudenterna sa och stannade för det mesta på en ideologisk nivå och nådde inte implementering.

Utifrån analysen av observationer och intervjuer med lärare och fokusstudenter blir det tydligt att det finns ideologier som innebär att lärare och studenter med en svenskspråkig bakgrund uppfattar bristen vad gäller språklig korrekthet i relation till standardsvenska som ett huvudproblem, i synnerhet i relation till skriven svenska som följer akademiska standardnormer. Trots att utrymme gavs och användes av fokusstudenterna att prestera på seminarier och vid muntliga presentationer, och trots att de vid observationerna ofta presterade väl muntligt, inklusive när de använde digitala verktyg så som Power Pointpresentationer och mobiltelefoner, värdesattes de skriftliga uppgifterna utifrån standardnormer högre. Samtidigt som lärarutbildarna uttryckte positiva attityder gentemot studenternas mångfald inkluderade de enbart svenska (och i någon mån engelska) i programmets undervisningspraktiker. När lärarutbildarna talade om språk i relation till fokusstudenterna, nämnde de inte explicit vilket språk eller vilka normer. I detta fall blev uppfattade (svensk-)språkliga brister ett problem, inte bara för programmet utan även, implicit, för arbete som förskollärare, eftersom studenter inte kan bli förskollärare utan att visa förmåga att producera skriftliga arbeten enligt stipulerade normer om lämplighet. 


\subsection{Skapande, upprätthållande, förhandling och utmaning av språkliga ideologier}

I detta avsnitt analyseras hur de språkliga ideologier som framträder skapas, upprätthålls, förhandlas och utmanas. Den enspråkiga normen som fokusstudenterna kämpade med att anpassa sig till, och den akademiska norm som de flesta studenter kämpade med, inklusive de som kategoriserades som svenska studenter, blev särskilt synlig vid praktiker kopplade till bedömning och betygsättning. Som nämnts ovan arbetade lärarutbildarna hårt med att socialisera studenterna in i det akademiska skrivandet, men för att hantera de upplevda problemen sa lärarutbildarna att de hade kommit överens om att prioritera innehållet framför språklig korrekthet vid bedömningen. Vissa nämnde explicit olika slags skriftliga uppgifter som de gav studenterna för att hjälpa dem att utveckla sina skrivfärdigheter, såsom laborationsrapporter, fältstudierapporter och akademiska uppgifter. På en fråga om lärarna sinsemellan hade diskuterat hur de skulle förhålla sig till krav på skrivfärdigheter, berättade en lärarutbildare under intervjun hur hon anpassade uppgifterna utifrån den överenskommelsen och i relation till de lärare som fungerade som språkstöd:

Excerpt 6.

och gjorde vi som så då att vi tittade på innehållet vi lärare seminarielärare som bedömde vi tittade på innehållet och sen fick dom chansen att med I och R [språkstödslärare] stöd hyfsa det språkliga så att det blev godtagbart (m) det här var ju första då och det här är ju en fråga som vi får fortsätta att vrida och vända på hur vi ska se på dom här kraven men då bestämde vi oss då efter diskussion att det är innehållet som är det viktigaste.

På så sätt strävade lärarutbildarna efter att upprätthålla normen genom anpassning av uppgifter och stöd för studenternas språkanvändning snarare än att ifrågasätta den. Frågan om språkliga normer och anpassade uppgifter var ett ämne som togs upp av flera lärarutbildare i intervjuerna. En pågående fråga var om de skulle sänka nivåerna när det gällde språklig korrekthet och inrikta sig på innehållet. Lärarutbildarna diskuterade också rättvisan i att vissa studenter gavs mer tid under examinationer eller mer hjälp med argumentet att alla borde behandlas lika. På så vis kan man förstå lärarnas ansträngningar att upprätthålla den rådande normen som en objektiv måttstock som alla skulle bedömas i relation till. Lärarna strävade således efter en likvärdighet genom att alla behandlades lika oavsett behov. För att stötta och socialisera studenterna in i en svenskspråkig akademisk norm beskrev lärarutbildarna hur de anpassade och förändrade undervisningspraktiken. Ett exempel är lärarutbildarnas tal om hur de medvetet arbetade med att stödja studenternas språk så att de uppnådde den förväntade normen. En lärarutbildare försäkrade sig om att undervisningsplaneringen gav tid för studenterna att skriva, få språkstöd och rätta. En annan sa att hon såg behovet av att utveckla en gemensam översikt över skrivandet i olika kurser genom hela programmet för att skapa progression i studenternas skrivande. Många lärarutbildare beskrev hur de avsiktligt stödde studenterna i deras skrivande genom handledning, explicit 
träning steg för steg och stöd via e-post. Det blev tydligt att lärarna lade ner mycket kraft på att utveckla sätt att stödja studenterna att uppnå de föreskrivna normerna för akademiskt skrivande.

Lärarutbildaren som arbetade med språkstöd uppfattade att de skriftliga uppgifterna, ur ett språkligt perspektiv, var de svåraste för studenterna att fullfölja och sa att hon ofta gick igenom en text många gånger innan studenten kunde lämna in den. Hon framhöll vid intervjun att det svenska språket var ett större hinder för fokusstudenterna än själva kursinnehållet.

Excerpt 7.

det är språket mest så att dom alltså så att själva ämnet upplever jag att dom kan väldigt mycket om just förskolan och teorier och sånt där, det upplever jag inte som ett problem men det är språket när dom skriver fel ordföljd eller kanske fel ordval och eh verbböjningar och sånt som gör att man inte förstår meningen, man får inget sammanhang då, så förstår inte vad det står just då så då blir det förvirrande har jag liksom mest hjälpt dom språkligt ... för att det ska bli tydligt.

Samtidigt konstaterade lärarutbildaren som gav språkstödet vid slutet av första terminen att det var några av lärarna som inte ville att studenterna först lämnade in till språkstödet innan de lämnade in till kursens lärare, eftersom de upplevde att dessa studenter fick extra hjälp, vilket inte var rättvist gentemot övriga studenter. De ansåg alltså språkstödet stå i konflikt med kravet på likvärdighet. Språkstödsläraren motsatte sig detta och argumenterade att det var logiskt att fokusstudenterna skulle få språkstöd. På så sätt kan man säga att även själva upprätthållandet av normen förhandlades mellan språkstödsläraren och övriga lärare i programmet.

Sammanfattningsvis visade analysen av materialet endast ett fåtal försök eller möjligheter att förhandla den rådande normen från lärarnas och studenternas sida. För att socialisera fokusstudenterna in i en enspråkig, standardiserad norm gavs praktiker som språkstödet stor vikt, särskilt under studenternas första sex månader. Sålunda upprätthölls den rådande normen genom anpassning av uppgifter och stöd. De diskussioner som fördes mellan lärare om anpassning av uppgifter, om fokus på innehåll i stället för form och om språkstöd och utsträckt tid vid examination kunde vara förenligt med villkor för likabehandling, kan möjligtvis betraktas som en form av förhandling av den rådande normen. I slutändan utmanades dock normen aldrig, något som blev tydligt vad gäller det slutliga examensarbetet, ett arbete som ingen av de deltagande fokusstudenterna lyckades uppnå godkänt resultat på inom den stipulerade tiden.

\subsection{Positionering av studenterna i relation till språkliga ideologier}

I detta steg analyseras hur studenterna positioneras och positionerar sig i relation till ovan nämnda ideologier. Eftersom en enspråkig norm för standardspråklig akademisk svenska rådde inom utbildningspraktikerna, positionerades fokusstudenterna som bristfälliga i relation till de språknormer som betraktades 
som lämpliga både vid lärosätet och under fältstudierna. Efter ett seminarium, där i synnerhet de deltagande fokusstudenterna hade genomfört mycket väl förberedda presentationer, uttryckte den undervisande läraren till den observerande forskaren att detta hade förvånat henne, eftersom hon hade fått höra från kollegor att just dessa studenter presterade svagt. Det observerades flera exempel på att fokusstudenterna själva positionerade sig som goda studenter som var väl förberedda, såsom i följande exempel. Under ett matematikseminarium om symmetri var de två fokusstudenterna i seminariegruppen de enda som hävdade att de hade arbetat med utdelade övningar för att förbereda sig inför seminariet. En av dem visade upp displayen på sin mobil för att visa ett fotografi av en stad som speglades i en sjö som ett exempel på symmetri. Sålunda arbetade dessa studenter hårt med att positionera sig själva som goda studenter genom att använda lämpliga resurser så som Power Point och standardiserad svenska i sina presentationer och att samtidigt visa hur de förberedde sig för seminarierna genom att lära sig av och arbeta med litteraturen, som var på såväl svenska som engelska.

I lärosätets språkpolicy fastställdes att lärosätet mot bakgrund av en breddad rekrytering och ett internationellt engagemang tar emot studenter som inte har svenska som modersmål eller saknar erfarenhet av ett vetenskapligt språk, och att det därför är en viktigt del av lärares uppdrag att uppmärksamma sådana förhållanden samt att tillsammans med studenten söka vägar för att utveckla språket i riktning mot "det offentliga och vetenskapliga språkets norm”. Man kan därför förstå denna policy som att den öppnade rum för positionering av studenter med andra modersmål än svenska som studenter som kan vara i behov av specifikt stöd. Utvidgat språkstöd och förändringar i bedömningsformer kan därmed betraktas som rum för implementering av denna policy om stöd och anpassning.

När det gäller språklig mångfald positionerades emellertid studenterna med sina varierade språkliga repertoarer som en resurs, vilket å ena sidan öppnade ett ideologiskt rum för språklig mångfald och pluralism, medan å andra sidan utrymmet för implementering var begränsat. Andra språkliga repertoarer än svenska, och i viss mån engelska, osynliggjordes och deras potential som tillgångar förbisågs, vilket gällde alla studenter generellt och fokusstudenterna i speciellt. Lämpligt språk för deras framtida yrke som förskollärare begränsades till svenska, och det var endast i mycket begränsad omfattning som studenterna uppmuntrades eller gavs pedagogiska redskap att använda sina flerspråkiga repertoarer som resurser under sina akademiska studier.

Analysen visar att en enspråkig norm uppfattades som objektiv och neutral, och sålunda var det den Andre, andraspråksstudenten, som positionerades som språkligt bristfällig, som ännu inte redo för programmet eller som ännu inte behärskande den dominerande språkliga formen. Detta visar på en språklig hierarki, där standardsvenska (och i viss utsträckning engelska) betraktas som dominerande och lämplig. Jämfört med tidigare forskning om engelskans starka position i högre utbildning (Melander, 2007; Salö, 2010) visar denna studie att för dessa studenter,, som kategoriserades som immigranter eller med utländsk 
bakgrund, var det deras uppfattade svaga svenskspråkiga färdigheter som var i fokus. Engelska nämndes varken i intervjuer eller under observationer.

Denna positionering som annorlunda utmanade aldrig studenterna själva, utan i stället betonade de sin vilja till anpassning, såsom den student som hävdade att det var otänkbart för henne att använda somaliska till ett barn i förskolan. Ett annat exempel är en student, som under en intervju fick frågan om hon hade sjungit något från sitt hemland för barnen, svarade att hon mycket väl kunde Lilla snigel. Trots att ideologiskt explicita positiva uttryck vad gäller flerspråkighet och mångfald sålunda uttrycktes på olika sätt vid lärosätet, visar analysen att fokusstudenterna positionerades som varande i behov av anpassning till den dominerande språkliga normen.

\section{Diskussion}

Syftet med denna studie har varit att utforska språkideologier i svensk lärarutbildning genom att undersöka hur ideologiska rum och rum för implementering av språklig mångfald konstrueras inom förskollärarprogrammet vid ett svenskt lärosäte. Detta har gjorts genom att via observationer och intervjuer följa en grupp fokusstudenter som antogs till programmet på grund av sin migrationsbakgrund. Analysen visar på en rådande enspråkig norm för standardiserad svenska såväl i förskoleutbildningen som för studenternas framtida arbete som förskollärare, och att en förutsättning för att bli enerkänd medlem i denna grupp var att följa denna norm.

I den politiska diskursen har breddad rekrytering till högre utbildning länge framhållits som ett viktigt värde och alla lärosäten har sedan 2001 ett uppdrag att främja och bredda rekryteringen. Särskilda satsningar på snabbspår för lärare med examen från andra länder än Sverige har skapats för att förenkla vägarna in i läraryrket i Sverige. Med utgångspunkt i studiens resultat ställer vi dock frågan i vilken mån högre utbildning dels anpassas för att möta en mer heterogen studentgrupp, dels synliggör och värdesätter deras erfarenheter och kunskaper. Studien synliggör hur lärarutbildare arbetar för att socialisera in studenterna i en enspråkig svensk akademisk norm för att de ska kunna lyckas i utbildningen och hur de genom olika anpassningar försöker stödja studenterna. Varken studenter eller lärarutbildare ifrågasätter dock normen och en standardiserad akademisk svenska framställs istället som neutral.

Resultaten har visat en spänning mellan å ena sidan pluralism och mångfald, och å andra sidan ett starkt krav på anpassning av språkanvändning för minoritetsstudenter, såsom denna fokusgrupp, till en enspråkig standardiserad norm, på samma sätt som tidigare resultat av Blåjsö (2004), LennartssonHokkanen (2016) and Bigestans (2015) har visat. Normer som uttrycks implicit är svåra att utmana, såsom i detta fall det faktum att språkanvändning och -normer enbart inkluderar svenska och i viss mån engelska. Liksom Paulsrud och Zilliacus 
(2018) identifierar vi ideologiska rum för språklig mångfald genom det värde dessa studenter anses föra med till lärarutbildning och till framtida förskolor tack vare sin migrationsbakgrund, där språklig bakgrund explicit nämns, medan rum för implementering är svåra att finna. På det sättet kan lärarutbildning bli en arena för studenter med olika språkliga bakgrunder där de anpassar sig eller assimileras till den svenska enspråkiga normen, medan andra delar av deras språkliga repertoarer exkluderas från deras professionella identiteter som förskollärare. Om studenter inte uppmuntras att visa upp och använda sina varierade språkliga repertoarer under lärarutbildningen och de verksamhetsförlagda delarna, är det osannolikt att de kommer att göra så under sin yrkeskarriär. Samtidigt som studenter med olika bakgrund således uppmuntras att bli förskollärare och lärare, görs samma bakgrund osynlig eller betraktas som ett problem att lösa.

Liksom Flores and Rosa (2015; Rosa \& Flores, 2017) vill vi hävda att om språknormer behandlas som objektiva blir de en legitim arena för krav på assimilering till en enspråkigt svensk standardnorm och kan då även ge utrymme för andra uttryck av främlingsfientlighet. För att lärarutbildare ska kunna motarbeta sådana tendenser och stärka mångfalden bland studenterna, inklusive språklig mångfald, är det viktigt att undervisningsformer utvecklas som inbjuder varierade språkliga resurser liksom kulturell mångfald. Detta borde också inkludera en omvärdering av värden som utgör basen för det svenska utbildningssystemet, i detta fall förskolan.

Som lärarutbildare inser vi värdet och kanske nödvändigheten av en gemensam språklig norm, och även att denna i hög grad behöver gälla skriven text. Samtidigt argumenterar vi för att öppna lärarutbildningen för en flerspråkig pedagogik som inkluderar och stärker en varierad språklig repertoar bland studenter. Detta skulle i högre grad skapa utrymme för att arbeta i förskolor och skolor i vårt nutida pluralistiska samhälle. Vi finner det sålunda nödvändigt att skapa sådana rum för språklig mångfald för vår tids lärarutbildning och i förlängningen för hela skolsystemet.

\section{Tack}

Ett tack riktas till de lärare och studenter som medverkade i denna studie samt till Skolforskningsfonden i Dalarna för ekonomiskt stöd för studiens genomförande. 


\section{Om författarna}

Åsa Wedin er Professor ved Högskolan Dalarna. Wedin är fil dr i tvåspråkighetsforskning och professor i Pedagogiskt arbete vid Högskolan Dalarna. Hon arbetar med lärarutbildning och forskning med inriktning mot flerspråkighet och litteracitet med särskilt intresse för yngre barn och vuxna. Institutionsanknytning: Högskolan Dalarna, 79188 Falun, Sverige. E-post: awe@du.se

Jenny Rosén er docent ved Stockholms universitet. Rosén är docent i svenska som andraspråk vid Stockholms universitet. Hennes forskningsintressen är inriktade mot flerspråkighet, mångfald och litteracitet inom olika utbildningskontexter. Institutionsanknytning: Stockholms universitet, 10691 Stockholm, Sverige. E-post: jenny.rosen@isd.su.se

\section{Referenser}

Alim, S. H. (2016). Introducing raciolinguistics: Racing language and languaging race in hyperracial times. I H. S. H. Alim, J. R. Rickford, \& A. F. Ball (Red.), Raciolinguistics: How language shapes our ideas about race, (s. 1-30). Oxford University Press.

Bayati, Z. (2014). "Den Andre i lärarutbildningen: En studie om den rasifierade svenska studentens villkor i globaliseringens tid. [Doktorsavhandling, Göteborgs universitet]. https://gupea.ub.gu.se/bitstream/2077/35328/1/gupea_2077_35328_1.pdf

Bigestans, A. (2015). Utmaningar och möjligheter för utländska lärare som återinträder i yrkeslivet i svensk skola. [Doktorsavhandling, Stockholms Universitet]. http://su.divaportal.org/smash/get/diva2:773560/FULLTEXT01.pdf

Blackledge, A. \& Creese, A. (2010). Multilingualism: a critical perspective. London: Continuum.

Blackledge, A. \& Creese, A. (2014). Heteroglossia as practice and pedagogy. I A. Blackledge \& A. Creese (Red.), Heteroglossia as practice and pedagogy (s.1-20). Springer Netherlands.

Blommaert, J. (2010). The sociolinguistics of globalization. Cambridge University Press. Blommaert, J. \& Rampton, B. (2012). Language and superdiversity. MMG Working Paper 12-09, Max-Planck-Institut zur Erforschung multireligiöser und multiethnischer Gesellschaften, Max Planck Institute for the Study of Religious and Ethnic Diversity. https://pure.mpg.de/rest/items/item_1615144_3/component/file_1615143/content

Blåsjö, M. (2004). Studenters skrivande i två kunskapsbyggande miljöer. [Doktorsavhandling, Stockholms universitet]

Boyd, S. \& Huss, L. (Red.). (2001). Managing multilingualism in a European nation-state: Challenges for Sweden. Multilingual Matters.

Canagarajah, S. (2018). The unit and focus of analysis in lingua franca English interactions: In search of a method. International Journal of Bilingual Education and Bilingualism, 21(7), 805-824. https://doi.org/ 10.1080/13670050.2018.1474850

Conteh, J. \& Meier, G. (Red.). (2014). The multilingual turn in languages education: Opportunities and challenges. Multilingual Matters. 
Fishman, J. (1974). Language planning and language planning research: the state of the art. I J. Fishman (Red.), Advances in language planning (s.15-34). The Hague: De Gruyter Mouton.

Flores, N. \& Rosa, J. (2015). Undoing appropriateness: Raciolinguistic ideologies and language diversity in education. Harvard Educational Review, 85(2), 149-171. https://doi.org/10.17763/0017-8055.85.2.149

Gal, S. (2006). Migration, minorities and multilingualism: Language ideologies in Europe. I C. Mar-Molinero \& P. Stevenson (Red.), Language ideologies, policies, and practices: Language and the future of Europe (s. 13-27). Palgrave Macmillan.

García, O. (2009). Bilingual education in the $21^{\text {st }}$ Century: A global perspective. Blackwell Publishers.

Gunnarsson, B.-L. (2004). Svenska, English eller Deutsch: Om språksituationen vid svenska universitet och högskolor. I Svenska språknämnden. Engelskan i Sverige: Språkval i utbildning, arbete och kulturliv (s. 111-133). Norstedts ordbok.

Haugen, E. (1972). The ecology of language: Essays. Stanford: Stanford University Press.

Hermansson, C., Norlund Shaswar, A., Rosén, J. \& Wedin, Å. (2021). Teaching for a monolingual school? (In)visibility of multilingual perspectives in Swedish teacher education. Education Inquiry (s. 1-17). https://doi.org/10.1080/20004508.2021.1885588

Holm, L. \& Pitkänen-Huhta, A. (Red.), (2012). Literacies in transition: Perspectives from the Nordic countries. Multilingual Matters.

Hornberger, N. (2005). Opening and filling up implementational and ideological spaces in heritage language education. The Modern Language Journal, 89(4), 605-609.

Hornberger, N., \& Johnson, D. C. (2007). Slicing the onion ethnographically: Layers and spaces in multilingual language education policy and practice. TESOL Quarterly, 41(3), 509-532.

Hult, F. M. \& Källkvist, M. (2016a). Global flows in local language planning: Articulating parallel language use in Swedish university policies. Current Issues in Language Planning, 17(1), 56-71. https://doi.org/10.1080/14664208.2016.1106395“

Hult, F. M. \& Källkvist, M. (2016b). Discursive mechanisms and human agency in language policy formation: Negotiating bilingualism and parallel language use at a Swedish university. International Journal of Bilingual Education and Bilingualism, 19(1), 1-17. https://doi.org/10.1080/13670050.2014.956044

Hummelstedt-Djedou, I., Zilliacus, H., \& Holm, G. (2018). Diverging discourses on multicultural education in Finnish teacher education programme policies: Implications for teaching, Multicultural Education Review, 10(3), 184-202. https://doi.org/

10.1080/2005615X.2018.1511341

Högskoleförordningen, Bilaga 2 1993:100 https:/www.riksdagen.se/sv/dokumentlagar/dokument/svensk-forfattningssamling/hogskoleforordning-1993100_sfs-1993-100

Högskolelagen (1992:1434). https://www.riksdagen.se/sv/dokument-lagar/dokument/svenskforfattningssamling/hogskolelag-19921434_sfs-1992-1434

Kell, C. (2017). Travelling texts, translocal/transnational literacies and transnational analysis. I Canagarajah, S. (Red.), The Routledge handbook of migration and language. (s. 413430). Taylor and Francis Group.

Lennartsson-Hokkanen, I. (2016). Organisation, attityder, lärandepotential: Ett skrivpedagogiskt samarbete mellan en akademisk utbildning och en språkverkstad. [Doktorsavhandling, Stockholms universitet]. http://su.divaportal.org/smash/get/diva2:1038845/FULLTEXT01.pdf

Makoni, S. \& Pennycook, A. (Red.), (2007). Disinventing and reconstituting languages. Multilingual Matters. 
McGroarty, M. E. (2010). Language and ideologies. I Hornberger, N. \& McKay, S. (Red.), Sociolinguistics and language education (s. 3-39). Cambridge University Press.

May, S. (Red.). (2014). The multilingual turn: Implications for SLA, TESOL and bilingual education. Routledge.

Melander, B. (2007). Språkpolitik och språkvård. I E. Sundgren (Red.), Sociolingvistik (s. 310-335). Liber.

Molina, I. (2005). Rasifiering: Ett teoretiskt perspektiv i analysen av diskriminering i Sverige. I Utredningen om makt, integration och strukturell diskriminering (2005). Bortom vi och dom: Teoretiska reflektioner om makt, integration och strukturell diskriminering: Rapport (s. 95-112). Fritzes offentliga publikationer.

Paulsrud, B. \& Zilliacus, H. (2018). En skola för alla: Flerspråkighet och transspråkande i lärarutbildningen. Paulsrud, B., Rosén, J., Straszer, B. \& Wedin. Å. (Red.), Transspråkande och utbildning i svenska utbildningssammanhan (s. 27-48). Studentlitteratur.

Paulsrud, B. \& Lundberg, A. (2021). "One School for All? Multilingualism in Teacher Education in Sweden". Wernicke, M., Hammer, S. \& Hansen, A. (Red.) Preparing teachers to work with multilingual learners. Multilingual Matters, (s. 38-57). https://doiorg.www.bibproxy.du.se/10.21832/9781788926119-005

Phillipson, R. \& Skutnabb-Kangas, T. (1986). Linguicism rules in education. Roskilde University center, Institute VI.

Phillipson, R. (1992). Linguistic imperialism. Oxford Univ. Press.

Ramanathan, V. (2005). The English-vernacular divide: Postcolonial language politics in Practice. Multilingual Matters.

Ricento, T. \& Hornberger, N. H. (1996). Unpeeling the onion: Language planning and policy and the ELT professional. TESOL Quarterly, 30(3), 401-427.

Rosa, J. \& Flores, N. (2017). Unsettling race and language: Toward a raciolinguistic perspective. Language in Society, 46(5), 621-647

Rosén J. \& Wedin, Å. (2018). Same but different. Negotiating diversity in Swedish pre-school teacher training. Journal of Multicultural Discourses, 13(1), 52-68. https://doi.org/10.1080/17447143.2018.1426589

Rosén, J. \& Wedin, Å. (2019). Att representera mångfalden: Förskollärarstudenters narrativ om representativitet, delaktighet och professionalitet. I: E. Remiers, M. Harling, I. Henning Loeb \& K. Rönnerman, (Red.) Lärarprofession i en tid av förändringar: Konferensvolym från den tredje nationella ämneskonferensen i pedagogiskt arbete (s. 6580). Göteborgs universitet.

Ruiz, R. (1984). Orientations in Language Planning. NABE Journal, 8(2), 15-34

Salö, L. (2010). Engelska eller svenska? En kartläggning av språksituationen inom högre utbildning och forskning. Rapporter från språkkommittén. Språkrådet.

SFS 2009:600 Språklag. Kulturdepartmentet. https://www.riksdagen.se/sv/dokumentlagar/dokument/svensk-forfattningssamling/spraklag-2009600_sfs-2009-600

Skilton-Sylvester, E. (2002). Should I stay or should I go?: Investigating Cambodian women's participation and investment in adult ESL programs. Adult Education Quarterly. 53(1), 9-26.

Skolverket (2011). Läroplan för grundskolan, förskolan och fritidshemmet 2011. Skolverket.

Skolverket (2019). Elever och skolenheter i grundskolan läsåret 2018/19. https://www.skolverket.se/download/18.6bfaca41169863e6a65e7b1/1554323705043/pdf4 060.pdf

Skolverket (2020). Behörigheten till gymnasieskolan ökar i alla elevgrupper. https://www.skolverket.se/om-oss/press/pressmeddelanden/pressmeddelanden/2020-0924-behorigheten-till-gymnasieskolan-okar-i-alla-elevgrupper 
Universitets- och högskolerådet (2016). Can excellence be achieved in homogeneous student groups? A report on the governmental assignment to survey and analyse the work of Swedish higher education institutions on widening access and widening participation. https://www.uhr.se/globalassets/_uhr.se/publikationer/2016/uhr-can-excellence-beachieved-in-homogeneous-student-groups.pdf

Utbildningsdepartementet (2018). Uppdrag om att skapa fler vägar in i läraryrket Diarienummer: U2018/03202/UH. https://www.regeringen.se/regeringsuppdrag/2018/08/uppdrag-om-att-skapa-fler-vagarin-i-lararyrket/

Vertovec, S. (2007). Super-diversity and its implications, Ethnic and Racial Studies, 30(6), 1024-1054, https://doi.org/10.1080/01419870701599465

Vertovec, S. (2019). Talking around super-diversity, Ethnic and Racial Studies, 42(1), 125139, https://doi.org/10.1080/01419870.2017.1406128

Zilliacus, H., Paulsrud, B. \& Holm, G. (2017). Essentializing vs. non-essentializing students' cultural identities: Curricular discourses in Finland and Sweden, Journal of Multicultural Discourses, 12(2), 166-180, https://doi.org/10.1080/17447143.2017.131133 